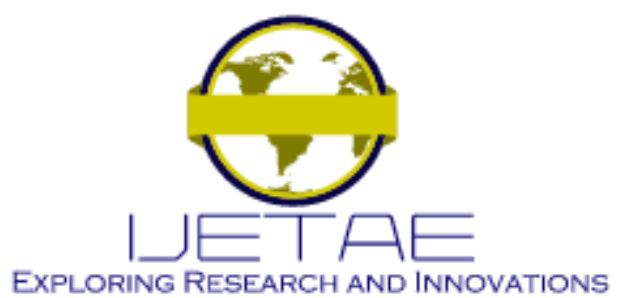

International Journal of Emerging Technology and Advanced Engineering

Website: www.ijetae.com (E-ISSN 2250-2459, Scopus Indexed, ISO 9001:2008 Certified Journal, Volume 11, Issue 11, November 2021)

Manuscript Received: 15 September 2021, Received in Revised form: 03 November 2021, Accepted: 12 November 2021

DOI: 10.46338/ijetae1121_06

\title{
The Beginning of the Glass Age with Holographic Game Technology
}

\author{
Yogi Udjaja ${ }^{1}$, Chang Minhuei ${ }^{2}$ \\ ${ }^{1,2}$ Computer Science Department, School of Computer Science, Bina Nusantara University, Jakarta Indonesia 11480
}

\begin{abstract}
The development of technology has now begun to shift to society $\mathbf{5 . 0}$, this technology has helped many human activities. The development of technology is also followed by the development of games, games in holographic form have been made by several developers, however, there are not many games in the holographic form that are marketed and played by many players. Hologram technology is a technology that is starting to develop at this time. There have been several games made from holograms, in fact, there are already tools to view or display holographic shapes. This paper explains that the creation and development of games using holographic technology has been around for decades. The development of the times has slowly begun to expand and develop knowledge about hologram technology by making hologram games and adding or developing ways of interacting with these hologram games.
\end{abstract}

Keywords-Hologram Game Technology, 3D Hologram, Hologram for Game, Modern Technology.

\section{INTRODUCTION}

Along with the development of the times, technology is increasingly sophisticated and makes human activities easier. Technology will continue to evolve and new technologies will continue to emerge over time. Starting from simple electronic devices, to robots with Artificial Intelligence technology, technology changes a lot of human habits, such as habits in communicating, transacting, studying, and so on.

Society 5.0 is the use or application of modern technology to serve or assist human needs in various fields. Society 5.0 helps people carry out activities or daily needs with current technology. Society 5.0 was inaugurated on January 21, 2019 and was initiated by Japan, which is a country that is developing technology rapidly. Society 5.0 was created to minimize economic problems and inequality in society by using technology. The more technology develops, the easier and more practical human activities are [1].
One of the technologies currently developing is hologram technology. Hologram is a technology that records the shape of an object's appearance and then displays the recorded object in 3-dimensional form [2]. The combination of two related or related lights can form a hologram. The advantage of a hologram is the ability to record and store the shape or information of 3-dimensional objects. At present, hologram technology has been found in several countries with various functions. Holograms can function as a medium for introducing domestic animals, media for introducing the means of transportation, media for the introduction of the 7 wonders of the world, media for the introduction of Indonesian herbal spices, media for introducing the solar system, media for introducing traffic signs, media for promoting home sales, media for educational simulations and others. [3-10]. There are many functions of the 3dimensional hologram that can be used, from advertising, learning, introduction to science, simulation media, games, entertainment, show cases and others.

Currently, several companies have released tools for displaying images with holograms. Tools for displaying holographic shapes have various forms, some of which are fan-shaped, prism or pyramid, and others. Tools for displaying holograms that are widely used are tools in the form of prisms or pyramids because they are easy to use and the tools can be made by yourself with commonly-known materials and do not require large costs $[2,11]$.

The development of technology also affects game development because most games are played using existing technology. The development of the game is growing rapidly and is favored by many lay people. At present, many online and offline game competitions are being held, this has resulted in the development of games in the international market.

Technology and games develop hand in hand, the emergence of new technologies will also lead to games involving and using these new technologies. 


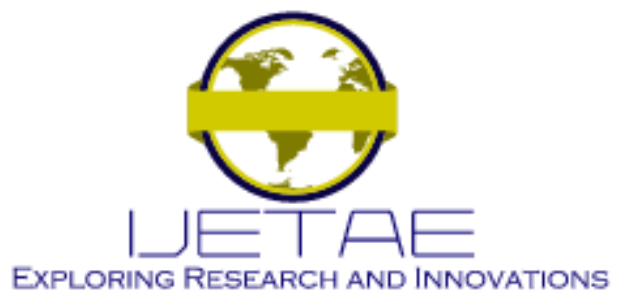

International Journal of Emerging Technology and Advanced Engineering

Website: www.ijetae.com (E-ISSN 2250-2459, Scopus Indexed, ISO 9001:2008 Certified Journal, Volume 11, Issue 11, November 2021)

Many game developers are competing to make games with new technology. Currently, there are several games made with a holographic display in 3-dimensional form, where the display can be seen not from just one screen.

\section{IMPLEMENTATION CRITERION}

\section{A. Hardware}

In making a 3-dimensional hologram, hardware is needed. Hardware is used as an intermediary medium between developers and systems or applications. One of the characteristics of hardware is that it can be touched by humans. Hardware consists of screen (monitor), keyboard, CPU, mouse, and other additional hardware [12]. Monitor is used to display the system. The keyboard is used for typing. CPU is used to cultivate or process the system. Mouse is used to move or direct the cursor on the system screen.

\section{B. Unity}

To make a game, an application is needed to make it. Unity is a game engine for making 3-dimensional games. Unity is software as a medium to combine or unite various assets and source code to create a game [13]. Unity is widely used by game developers because it is one of the free game engines.

\section{Hologram Projector}

A hologram projector is a tool for displaying light or images in the form of a hologram. The hologram projector collects or collects light to display hologram images [14]. Hologram projectors have various forms, some of which are a prism or pyramid-shaped hologram projector and a fan-shaped hologram projector. Making a hologram projector in the form of a prism is easier than making other hologram projectors [15]. A hologram projector with a fan shape has a propeller that rotates like a fan and displays a 3-dimensional image or illustration with the LED light on the propeller. Hologram projectors with fan shapes have been widely used or used in various fields such as entertainment, industry, advertising, exhibitions and others [16].

\section{HOLOGRAPHIC GAME RESEARCH}

The method used in this research is to search the data on the internet, through the Google and Google Scholar sites with the keywords "holographic" "game", "hologram game", and others.
The search results displayed are approximately 34,100 results from the site accessed on August 31, 2020.

TABLE I

RESEARCH ON HOLOGRAPHIC GAME TECHNOLOGY

\begin{tabular}{|c|c|c|c|}
\hline Year & Author & Title & Description \\
\hline 1987 & $\begin{array}{l}\text { Karabed } \\
\text { and } \\
\text { Mehrbians }\end{array}$ & $\begin{array}{l}\text { Holographic } \\
\text { Game Cards } \\
{[17]}\end{array}$ & $\begin{array}{l}\text { Cards game using } \\
\text { holographic technology. In } \\
\text { this game, the card is } \\
\text { shown as a 3-dimensional } \\
\text { hologram image. }\end{array}$ \\
\hline 1991 & McNulty & $\begin{array}{l}\text { Hologram } \\
\text { Game Card } \\
{[14]}\end{array}$ & $\begin{array}{l}\text { Game cards that use } \\
\text { holograms. Coated with } 3 \\
\text { layers, namely the first } \\
\text { layer contains hologram, } \\
\text { the second layer is the } \\
\text { support layer, and the third } \\
\text { layer is the cover layer } \\
\text { opposite to the support } \\
\text { layer. }\end{array}$ \\
\hline 1994 & $\begin{array}{l}\text { Trudeau } \\
\text { and } \\
\text { Pizairo }\end{array}$ & $\begin{array}{l}\text { Holographic } \\
\text { Display for } \\
\text { Pinball } \\
\text { Games [18] }\end{array}$ & $\begin{array}{l}\text { Pinball game using a } \\
\text { holographic display that } \\
\text { looks as if it is moving } \\
\text { towards the player. The } \\
\text { playing field is mounted on } \\
\text { a flexible plate. }\end{array}$ \\
\hline 1998 & $\begin{array}{l}\text { Kennedy } \\
\text { and } \\
\text { Nesbitt }\end{array}$ & $\begin{array}{l}\text { Game Ball } \\
\text { with a } \\
\text { Hologram } \\
\text { Image [19] }\end{array}$ & $\begin{array}{l}\text { Explanation of layers or } \\
\text { layers of research on the } \\
\text { hologram game made. The } \\
\text { first layer is coated with } \\
\text { acrylic polymer. The } \\
\text { reflective layer forms the } \\
\text { second layer. The third } \\
\text { layer is hot melt adhesive. }\end{array}$ \\
\hline 2005 & $\begin{array}{l}\text { Karabin } \\
\text { and } \\
\text { Stanek }\end{array}$ & $\begin{array}{l}\text { Gaming } \\
\text { Machine } \\
\text { Using } \\
\text { Holographic } \\
\text { Imaging [15] }\end{array}$ & $\begin{array}{l}\text { A game engine that uses } \\
\text { holographic technology. } \\
\text { Consists of } 2 \text { parts, namely } \\
\text { playing games and bonus } \\
\text { games. Bonus game using } \\
\text { interactive holographic } \\
\text { images. }\end{array}$ \\
\hline 2013 & $\begin{array}{l}\text { Boyd and } \\
\text { Brathwait } \\
\text { e }\end{array}$ & $\begin{array}{l}\text { Vocally } \\
\text { Interactive } \\
\text { Video Game } \\
\text { Mechanism } \\
\text { for } \\
\text { Displaying } \\
\text { Recorded } \\
\text { Physical } \\
\text { Characteristi } \\
\text { cs of a } \\
\text { Player in a } \\
\text { Virtual }\end{array}$ & $\begin{array}{l}\text { Game using a 3- } \\
\text { dimensional hologram and } \\
\text { microphone. Players will } \\
\text { be displayed in the game } \\
\text { world. Players can } \\
\text { communicate in-game by } \\
\text { talking. }\end{array}$ \\
\hline
\end{tabular}




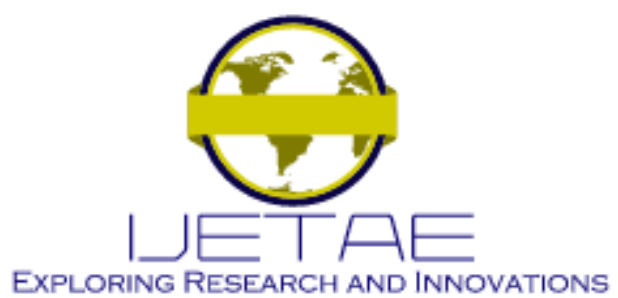

International Journal of Emerging Technology and Advanced Engineering

Website: www.ijetae.com (E-ISSN 2250-2459, Scopus Indexed, ISO 9001:2008 Certified Journal, Volume 11, Issue 11, November 2021)

\begin{tabular}{|c|c|c|c|}
\hline & & $\begin{array}{l}\text { World and in } \\
\text { a Physical } \\
\text { Game Space } \\
\text { Via One or } \\
\text { More } \\
\text { Holographic } \\
\text { Images [20] }\end{array}$ & \\
\hline 2015 & $\begin{array}{l}\text { Dalvi at } \\
\text { al. }\end{array}$ & $\begin{array}{l}\text { 3D } \\
\text { Holographic } \\
\text { Projections } \\
\text { using Prism } \\
\text { and Hand } \\
\text { Gesture } \\
\text { Recognition } \\
\text { [21] }\end{array}$ & $\begin{array}{l}\text { An image with a 3- } \\
\text { dimensional hologram that } \\
\text { can be interacted with } \\
\text { using sensors on the Hand } \\
\text { Gesture Device. A } \\
\text { hologram projector is in } \\
\text { the shape of a pyramid or } \\
\text { prism. Can be used for } \\
\text { product showcases or } \\
\text { exhibitions. }\end{array}$ \\
\hline 2017 & $\begin{array}{l}\text { Siang and } \\
\text { Mohamed }\end{array}$ & $\begin{array}{l}\text { BoBoiBoy } \\
\text { Interactive } \\
\text { Holographic } \\
\text { Action Card } \\
\text { Game } \\
\text { Application } \\
\text { [22] }\end{array}$ & $\begin{array}{l}\text { Holographic display card } \\
\text { game. The hologram is } \\
\text { displayed using a pyramid- } \\
\text { shaped hologram projector. } \\
\text { Players can interact with } \\
\text { the hologram using the AR } \\
\text { tracking technique. }\end{array}$ \\
\hline 2017 & $\begin{array}{l}\text { Oh and } \\
\text { Kwon }\end{array}$ & $\begin{array}{l}\text { Real-time } \\
\text { Implementat } \\
\text { ion of } \\
\text { Character } \\
\text { Movement } \\
\text { by Floating } \\
\text { Hologram } \\
\text { based on } \\
\text { Depth Video } \\
\text { [23] }\end{array}$ & $\begin{array}{l}\text { Converts human displays } \\
\text { into 3-dimensional } \\
\text { holograms and uses Kinect } \\
\text { to detect human } \\
\text { movements. When humans } \\
\text { move, the hologram that is } \\
\text { displayed will also move in } \\
\text { real-time and capture the } \\
\text { depth of the video. }\end{array}$ \\
\hline 2018 & $\begin{array}{l}\text { Tanaka } \\
\text { and } \\
\text { Fujimoto }\end{array}$ & $\begin{array}{l}\text { Proposal for } \\
\text { 9-squares } \\
\text { Shogi } \\
\text { Application } \\
\text { Utilizing 3D } \\
\text { Hologram } \\
\text { [24] }\end{array}$ & $\begin{array}{l}\text { An introduction to shogi } \\
\text { games with a } 3 \text { - } \\
\text { dimensional hologram } \\
\text { display. The size of this } \\
\text { shogi game is a } 3 \times 3 \text { board. } \\
\text { The holographic form of } \\
\text { the projector used is a } \\
\text { prism or pyramid. }\end{array}$ \\
\hline
\end{tabular}

From the results of the search and analysis obtained, the creation of games using holograms has been around since 1987. In 1987, technology was not developed and sophisticated enough as it is today, however, there have been several researchers or game makers who have tried to make games from technology. hologram. Before Society 5.0 era, hologram projectors were made with layers or layers and looked intricate.
However, developments in technology and science created new things, namely hologram projectors that were easier and more practical and could be made with commonly used materials. There are also hologram projectors that are more attractive and sophisticated that can be used for various activities, such as advertising, playing, entertainment, exhibitions, and others.

Games with 3-dimensional holograms are widely known and encountered today. Games with holographic displays are made with various ways of interaction, such as sensors, movement, AR tracking techniques, applications, and others. Currently games with holographic displays are mostly displayed with a hologram projector in the form of a pyramid or prism.

\section{RESUlTS AND ANALYSIS}

From the analysis obtained from the Google Scholar website, many researchers have written about games with holographic displays, but there are no unique and interesting games using holograms. However, from research obtained from the Google website, there are already several illustrations and tools or machines for holographic games $[15,25]$. Nowadays, games made of holograms have become known to the public. Technology will continue to develop, so that the development and research of games made of holograms at this time will continue to grow.

Hologram projectors in the form of prisms are widely used to display games in 3-dimensional form. Making a hologram projector in the form of a prism is relatively simple, easy and does not require a lot of money. A prismshaped hologram projector is usually placed on a screen. A hologram projector with a prism shape, does not record light or images, however, processes and displays direct light or images on the screen. Over time, technological developments have increased rapidly, tools for displaying and playing games using holographic technology have been developed by various researchers and technology companies.

Games made of holograms have been around since the 1980s. Games made of holograms are mostly board games and card games. Several technology companies are developing tools for displaying holograms and games that can be played with them. Many types of games can be played with today's holographic technology. Some games with hologram technology that are recommended and played by hologram technology users are RoboRaid, Dawn of Toys, Fragment, and others [26]. 


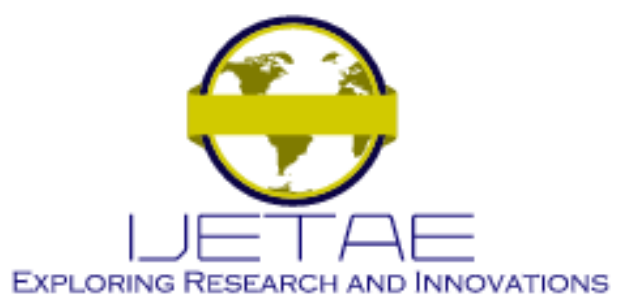

International Journal of Emerging Technology and Advanced Engineering

Website: www.ijetae.com (E-ISSN 2250-2459, Scopus Indexed, ISO 9001:2008 Certified Journal, Volume 11, Issue 11, November 2021)

\section{CONCLUSIONS}

Technology has developed very rapidly and facilitates activities or activities or human needs, this can be seen from the dependence of humans who always use or relate to this technology. Currently, holograms have begun to be developed, this can be seen from the emergence of tools to create 3-dimensional hologram images. This has been known by various groups and many people who know and participate in researching this matter. The hologram projector that is widely used today is a prism or pyramidshaped hologram projector, because it is easy to use and manufacture. The hologram game that is displayed using a hologram projetor prism, requires a 4-sided image or display to be displayed on the screen, then the hologram projector prism is placed on the screen, where one side of the prism is facing one image. Several tech companies have released tools for playing games with a holographic display.

Games made of holograms have been known since the 1980s, are relatively simple, but complicated and difficult to understand, due to inadequate science and technology at that time. Technology continues to evolve and currently making or researching games with holographic displays can be viewed and researched. From the results of the search and analysis, most of the games with holographic views are board games and card games. To date, there are no online games with holographic displays. Holographic games have been created by several game development companies. Games that already exist and are widely played or recommended for hologram technology users to try are Fragments, RoboRaid, Young Conker, and others.

Based on the existing literature, this is the beginning of the era of glass or smartglass, where soon all systems will be based on glass to increase user comfort.

\section{REFERENCES}

[1] Santoso, Muhamad Agung. (2019). Mengenal Lebih Jauh Society 5.0. Cited: 30 August 2020. Available from: https://www.kompasiana.com/muhamadagung/5cebcea995760e6fbe 242dea/mengenal-lebih-jauh-society-5-0

[2] Tawaqqal, I., Ningrum, I. P., \& Yamin, M. (2017). Hologram Holographic Pyramid 3 Dimensi. semanTIK, 3(1).

[3] Akbar, R., Listyorini, T., \& Latubessy, A. (2016). 3D Hologram Pengenalan Hewan Nusantara. Prosiding SNATIF, 19-24.

[4] Wahda, M. J., Listyorini, T., \& Meimaharani, R. (2017). 3D Hologram Pengenalan Alat Transportasi. Simetris: Jurnal Teknik Mesin, Elektro dan Ilmu Komputer, 8(1), 291-298. DOI: https://doi.org/10.24176/simet.v8i1.985
[5] FATIHUSSURUR, M. (2017). 3d Hologram Pengenalan 7 Keajaiban Dunia (Doctoral dissertation, UMK).

[6] Rifqy, M. (2017). 3d Hologram Pengenalan Rempah Herbal Asli Indonesia (Doctoral dissertation, Universitas Muria Kudus).

[7] Fuadi, M. M. (2017). 3d Hologram Pengenalan Sistem Tata Surya (Doctoral dissertation, Universitas Muria Kudus).

[8] AZZUHDI, A. (2018). APLIKASI 3D HOLOGRAM SEBAGAI MEDIA INTERAKTIF PENGENALAN RAMBU LALU LINTAS (Doctoral dissertation, Universitas Muria Kudus).

[9] WIBOWO, G. P. (2018). 3D HOLOGRAM SEBAGAI MEDIA PROMOSI PENJUALAN RUMAH DI PAKIS INDAH (Doctoral dissertation, UMK).

[10] Ramachandiran, C. R., Chong, M. M., \& Subramanian, P. (2019). 3D hologram in futuristic classroom: A review. Periodicals of Engineering and Natural Sciences, 7(2), 580-586. DOI: http://dx.doi.org/10.21533/pen.v7i2.441

[11] Rafi, Yuma. (2020). Yuk Berkenalan Dengan 'Kipas Hologram'. Cited: 31 August 2020. Available from: https://warstek.com/2020/08/30/yuk-berkenalan-dengan-kipashologram/

[12] Rahmayu, M., \& Sugiarto, S. (2017). Media Pembelajaran Mengenal Perangkat Keras Komputer Untuk Siswa Kelas IV SDN Tugu Utara 07 Pagi. Simnasiptek 2017, 1(1), 76-83.

[13] Blackman, S. (2013). Beginning 3D Game Development with Unity 4: All-in-one, multi-platform game development. Apress.

[14] McNulty, J. P. (1991). U.S. Patent No. 5,037,101. Washington, DC: U.S. Patent and Trademark Office.

[15] Karabin, J., \& Stanek, J. (2005). U.S. Patent Application No. $10 / 868,396$.

[16] Shaw, Corey. (2018). HoloLens Games to Look Forward to. Cited: 3 September 2020.2 Available from: http://thyblackman.com/2018/12/22/hololens-games-to-lookforward-to/

[17] Karabed, R., \& Mehrbians, R. (1987). U.S. Patent No. 4,681,324. Washington, DC: U.S. Patent and Trademark Office.

[18] Trudeau, J. T., \& Pizairo, E. S. (1994). U.S. Patent No. 5,316,303. Washington, DC: U.S. Patent and Trademark Office.

[19] Kennedy III, T. J., \& Nesbitt, D. (1998). U.S. Patent No. 5,762,573. Washington, DC: U.S. Patent and Trademark Office.

[20] Boyd, M., \& Brathwaite, S. (2013). U.S. Patent No. 8,523,673. Washington, DC: U.S. Patent and Trademark Office.

[21] Dalvi, A. A., Siddavatam, I., Dandekar, N. G., \& Patil, A. V. (2015, March). 3D holographic projections using prism and hand gesture recognition. In Proceedings of the 2015 International Conference on Advanced Research in Computer Science Engineering \& Technology (ICARCSET 2015) (pp. 1-5). DOI: https://doi.org/10.1145/2743065.2743083

[22] Siang, C. V., \& Mohamed, F. (2017). BoBoiBoy Interactive Holographic Action Card Game Application.

[23] Oh, K. J., \& Kwon, S. K. (2017). Real-time Implementation of Character Movement by Floating Hologram based on Depth Video. Journal of Multimedia Information System, 4(4), 289-294. DOI: https://doi.org/10.9717/JMIS.2017.4.4.289 


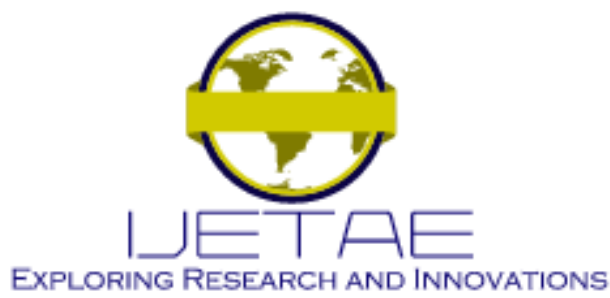

International Journal of Emerging Technology and Advanced Engineering

Website: www.ijetae.com (E-ISSN 2250-2459, Scopus Indexed, ISO 9001:2008 Certified Journal, Volume 11, Issue 11, November 2021)

[24] Tanaka, Y., \& Fujimoto, T. (2018). Proposal for 9-squares Shogi Application Utilizing 3D Hologram. In 2nd International Conference on Applied Cognitive Computing (pp. 34-40).

[25] Blain, Loz. (2018). Interview: Euclideon prepares to storm the arcade world with 3D hologram games. Cited : 15 Juli 2020. Available from: https://newatlas.com/euclideon-hologram-arcadegames/57334/
[26] Shaw, Corey. (2018). HoloLens Games to Look Forward to. Cited : 3 September $2020 . \quad$ Available from: http://thyblackman.com/2018/12/22/hololens-games-to-lookforward-to/

[27] Spector, A. Z. 1989. Achieving application requirements. In Distributed Systems, S. Mullende 